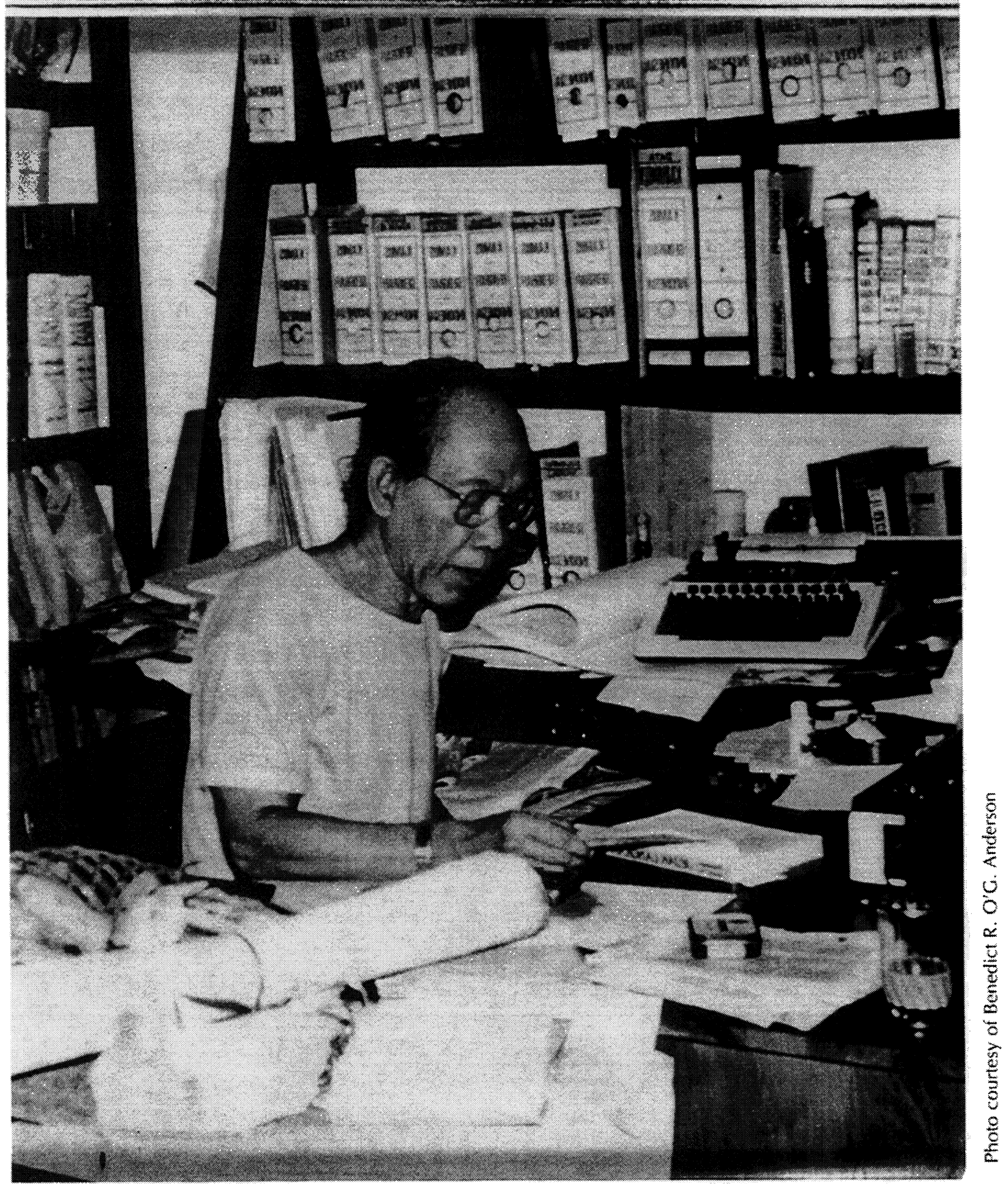

Pramoedya Ananta Toer 



\section{MY APOLOGIES, IN THE NAME OF EXPERIENCE ${ }^{1}$}

\section{Pramoedya Ananta Toer Translated with an Afterword by Alex G. Bardsley}

Since August 17, 1945, I have been a citizen of Indonesia, as have the tens of millions who were inhabitants of Indonesia then. I was twenty at the time. But I myself am of Javanese ethnic origin, and so I was educated from birth to become a Javanese, guided by the social-ethnic mechanism toward Javanese ideals, culture, and civilization. The power of this dominating, massive education came through oral and written literature, drama, music and song. These carried passages from the Mahabharata: a gigantic construction consisting of philosophical and ethical stories, religious references, and naturally, social and political prescriptions. Energy, imagination and effort were mobilized over centuries, bringing into being temples as well as myths about kings who scored big, and squeezing the local deities down to mere "kampung" gods. ${ }^{2}$ For this "millions" [sic] of humans throughout my ethnic group's history were butchered. Of course no official figure is available. It is clear, though, in line with the opinion of Cornell expert Ben Anderson, that at the climax of the Mahabharata, "they bathe in the blood of their own brothers." ${ }^{13}$ In their own times, it

\footnotetext{
1 Pramoedya Ananta Toer, "Maaf, atas nama pengalaman," Kabar Seberang 23 (1992): 1-9. Also published (by AKSI) in Progres 2 (1992). The Indonesian text may be found in the Indonesia list archives on the internet at: <URL: gopher://gopher.igc.apc.org:2998/7REG-INDONESIA>. Translated with permission from Kabar Seberang, James Cook University.

2 Kampung here suggests the narrow world-view of those without experience of what lies beyond their own immediate surroundings. Similar English terms generally carry a rural connotation that kampung does not, but "hick" or "bumpkin" is not far off the mark here.

3 And sisters: saudara here is not gender-specific, but like "brother" can suggest an affective as well as familial relation. The sound of Pramoedya's phrase is as beautiful as the image is horrible: mandi darah saudara-saudara sendiri. Pramoedya is probably referring to the introduction to Anderson's Language and Power: "Claire Holt reminded me that the most loved part of Javanese mythology was an indigenized
} 
is true, other peoples have experienced such a "kampung" civilization and culture too. Those who have managed to slip their shackles are the nations that rule the world.

At the start of the seventeenth century, Dutch society amassed the funds to finance sea-voyages in search of spices, voyages that crossed several oceans and touched a number of continents. In my country, a dozen-odd years later, in 1614 in fact, Sultan Agung, the strongest and most powerful of Java's kings, a king of the interior, of the second generation [in his lineage] and himself the third king of Mataram, destroyed the trading-port of Surabaya, simply because he needed acknowledgment of his power ${ }^{4}$ Here the irony of Javanese history is recorded: while the Dutch were circling the world in search of spices, Surabaya, a port of transit for the international consumption of those same spices, was demolished by a king of Java's interior, Sultan Agung.

Mataram itself was the second strong kingdom in Java to avoid the sea because it did not want to face the awesomeness of the sea-faring Portuguese. Sultan Agung also totally failed to expel the tiny Dutch colony at Batavia in 1629. This defeat led to Mataram's loss of the Java Sea, the international shipping passage of the period. To erase the shame Mataram suffered, and to defend its authority, the ethnic ${ }^{5}$ Javanese poets chirped that the founder of Mataram, Sultan Agung's father, had wedded the princess of the South Sea (south of the island of Java), Nyai Roro Kidul. To show, says Prof. H. Resink, that Mataram was still involved with the sea. ${ }^{6}$

In the ethnic Javanese chronicles, this particular Sultan is highly lauded while everything at all embarrassing is left out. (It is the same in history courses in the Republic of Indonesia today.) People's eyes would pop out if they kept up with what the Westerners write about him. As for the founder of Mataram, Sutawijaya, on the pretext of a broken promise (so the ethnic Javanese poets chant), he ascended the throne after killing his adoptive father, who had raised him and provided him with all the perks due a prince. None of the chronicles bequeathed to us ever touches on the subject of conscience, something which it seems indeed cannot be found in the Javanese vocabulary.

After the failure of Sultan Agung, his loss of power over the trade routes of the Java Sea, and the appearance of Western gunboats there, Java's middle class, which lived by ship-ownership, and the inter-island and international traders, were driven from the ports, herded into the interior, and went into decline. There they fell under the power of the aristocracy of the interior, whom they joined in decline.

version of the Mahabharata, which culminates in an orgy of bloodshed between close kinsmen." Benedict Anderson, Language and Power (Ithaca: Cornell University Press, 1990), p. 7.

4 Pramoedya provides Sultan Agung with a lengthy, heroic introduction, only to have him end in a temper tantrum. The word kekuasaan appears repeatedly: it stretches to cover power, domination, hegemony, even authority.

5 Pramoedya pokes at his readers by repeating the word ètnik and anachronisms such as internasional, along with a host of other English loan-words, to alert us (angrily, affectionately) to the way categories such as ethricity can be projected backwards in the process of inventing history, and to spoof the widespread use of Americanisms in the language of the "authentically Indonesian" New Order.

6. See Gertrudes Johan Resink, "Mers javanais," archipel 24 (1982): 97-100. Resink is the "Han" to whom Bumi Manusia and Anak Semua Bangsa are inscribed (see Kompas, August 29, 1980, p. 9). 
Still the court poets, servants of the power system, disregarded these symptomatic facts. After Sultan Agung's reign, Mataram-number-4 promptly made friends with the Dutch. The poets still took no notice. Instead, Nyai Roro Kidul was standardized as the lover of each king of Mataram, generation after generation, while her power expanded in such a fashion that she ultimately became a police-force. Strange but true, all this took place at the same time Java was, practically, beginning to embrace Islam. The spread of this new religion was not accompanied by its civilization, as had been the case with Hinduism, because it was, practically, a side effect of the chasing of Muslim traders from the sea-lanes by the power ${ }^{7}$ of the Christian West, a continuation of the expulsion of Arab power from the Iberian peninsula. One might say the spread of Islam was a side effect of the international Pan-Islamic movement of the period.

Even more startling is that, as this piece is written, Nyai Roro Kidul is taken for reality. One hotel on the south coast of West Java has a special room all prepared for this Goddess of the Southern Sea. How can it be that a country with the Pancasila as its ideology, of which Belief in One God is the first principle, accepts the presence of a sea goddess, the lover of the kings of Mataram? The poets never remember that, [even] with the unlimited power of the Goddess of the Southern Sea, not once did Mataram win in its confrontations with the Western power that came from the ends of the earth.

After the defeat of Sultan Agung, Java remained in thrall to its "kampung" civilization and culture, and was swallowed whole by the Dutch over three and a half centuries. Truly a moving tragi-comedy. For the Dutch arrived with no more strength than a mustard seed-a people few in number, from a small country at the northern tip of the world-having crossed the Atlantic, Indian, and Pacific Oceans. Even in the belly of Dutch power, Java still glorified its "kampung" civilization and culture, with its "kampung" climax: "they bathed in the blood of their own brothers," right up through 1965-66. . . . And because Java was no longer in the belly of European power, the slaughter clearly reached an unlimited scale.

Dutch, or European, colonization of my country did much to dampen these climaxes. Without colonization, my country would have ceaselessly spilled the blood of its sons and daughters. The struggle for second place after the Dutch in administrative power, [which took place] in Java in the middle of the eighteenth century, is said to have shed [the blood of] a quarter of all the inhabitants of the Javanese principalities. Yet the prince who took third place after the Dutch, Mangkunegara I, has recently been promoted to National Hero. Thus a foreign tourist who has some knowledge of Java and Indonesia would nod, understanding why, in the eighties nearing the end of the twentieth century, a statue of the Pandawa knights leaving for war on a chariot was erected on Jalan Thamrin, Jakarta. This is the image of the climactic phase of the Mahabharata, when "they bathe in the blood of their own brothers."

In three and a half centuries of colonization, my ethnic group's power never once prevailed against European power, not in any field, but especially not militarily. The poets and writers of Java, being some of those who think and imagine within the framework of "kampung" civilization and culture, flaunt the superiority of Java: that in

7 Kekuatan is sometimes also best translated as "power," but in a narrower and more instrumental (small p) sense than kekuasaan (see note above). 
4 Pramoedya Ananta Toer; Alex G. Bardsley, translator

facing the Dutch, and Europe, Java never lost. The masturbatory stories that are staged, and written, and even the stories spread by word of mouth, constitute one of the reasons I always ask: why does my ethnic group not want to face reality? The little knowledge I picked up in primary school and the little reading I have done in Western literature, at first unconsciously, but ever more forcefully, made me free myself from the "kampung" civilization and culture of my own ethnic origin. Once again-my apologies.

Outside Java, one ethnic group's power did triumph over Europe. This took place in Ternate in 1575. The Portuguese were driven out of their fort, and compelled to surrender. Because this took place somewhere other than Java, the surrendering troops were not made to bathe in their own blood. Instead they were escorted to the shore, and ordered to wait until the Portuguese fleet picked them up. And because this took place far from Java, in the Moluccas, it has never been touched upon in official history courses right up till today, in 1990. Maybe it will take until some foreign researcher's work is published. Or maybe it has been published, only it is just that I do not know.

Perhaps if earlier I had been educated in a particular discipline, history for example, I might do the research that would answer: why does all this happen and continue to happen? But I am a writer with minimal education, so it is not the materials of history that I examine, but its spirit. This I began with the tetralogy Bumi Manusia, particularly working on the currents that ebbed and flowed during the period of Indonesia's National Awakening. And so there came to be a new reality, a literary reality, a downstream reality, whose origin was an upstream reality, that is, a historical reality. ${ }^{8} \mathrm{~A}$ literary reality that contains within it a reorientation and evaluation of civilization and culture, which is precisely not contained in the historical reality. So it is that the literary work is a sort of thesis, an infant that on its own begins to grow in the superstructure of the life of its readers' society. ${ }^{9}$ It is the same with new discoveries in every field, that carry society a step forward.

I began deliberately with the theme of Indonesia's National Awakening-which, while limited regionally and nationally, nonetheless remains part of the world and of humanity. Step by step I am writing [my way] to the roots of its history, that for the moment is not ready to be published, or perhaps may never be published. In this way I have tried to answer: why did my people ${ }^{10}$ get to be like this, like that? So I do not write escapist fiction either, nor do I serve the status quo. Indeed I am outside of and have left the system that is "in effect." The outcome is very clear: I am thought a nuisance to the status quo in the system that is in effect. And because writing is a personal activity-even though the personal is also a product of the whole of society, present and past-the consequences have to be endured alone. And if sympathy arrives, wherever it comes from, to me it is a surplus value, that never entered my reckoning in advance. For that of course I give my thanks.

Before the tetralogy, I had already written a number of works, all of which would flow into it. And even back then the hostility of those who at the time were busy

\footnotetext{
${ }^{8}$ See Henk Maier's reading of this passage in his “Hikayat Dagang: Dari 'Syair Ken Tambuhan' ke Pramoedya Ananta Toer," kalam 4 (1995), at p.16.

${ }^{9}$ See Pramoedya's "Sastra Indonesia Timbul Sebagai Bangunan Atas," Bintang Timur, June 1, 1962.

10 For the first time, Pramoedya writes bangsaku instead of ètnikku.
} 
pursuing [their place in] the status quo had started. Surprisingly, in the beginning my works were well received, and indeed several times received awards. This was especially true during the period of Guided Democracy in the last years of the fifties and the first half of the sixties, the period of the Trisakti doctrine-political sovereignty, economic self-reliance, cultural integrity-a doctrine that, while universal among nationalist states everywhere, was, however, a bogey for the countries stuffed with capital, and hungry for new fields of enterprise around the world. History teaches much about the power of capital. Free peoples are enslaved; artless people are transformed into compradores; the unemployed become paid murderers with uniforms and badges of rank; vast forests are torn apart by infrastructure; cities and ports spring up out of nothing at its command; labor force is sucked in from all over, even from remote hamlets whose names no one has ever clearly heard. The governments of so many states it turns into mere instruments of its will; and when they are no longer wanted, they are overthrown. This is a boring story, one that is part of the experience of many peoples in the world. It is part of the experience of each person who shares the consequences, both the one who profits from it and the one who takes the loss. And each experience for a writer becomes the foundation for the creative process, no matter whether the experience is sensory or spiritual.

Would Indonesia with its independence accommodate itself to the power of capital that has no nationality, or would it challenge it as had been demonstrated during the 1945 revolution? As far back as in the revolutionary years, Soekarno had refused Ford's proposal that he give the company a monopoly in exchange for building a transSumatra-Java highway. During [the process of] development in the period of national independence, he was also the one who bypassed the alternatives of accommodation: capitalist bloc and communist bloc. Nor is it an accident that it was he who invented the term Third World. Whatever people's problems with his several weaknesses, it is clear he had a first-rate Indonesianness internal factor. He did not want his country to become part of any hemisphere-bloc. And Indonesia increasingly sank into economic difficulties. In these extraordinary economic difficulties I gave [him] my support, and naturally endured my portion of those difficulties. Support also came from almost every organization and movement, including movements that supported Soekarno to overthrow him. In that period LÉKRA made me a member of its Pleno. People say this organization was a front for the PKI. Even today it still amazes me: why is it that whatever is connected to the PKI is branded as something evil? It is clear, after all, that the party was a contestant in the general elections and came out one of the winners, not some "bandit" party without idealism. This means that the party was not a force already in power and applying its system of power. It is necessary that I emphasize the problem of power, because it is this that tends to turn people into bandits, above all if they have held it for decades and, without ever knowing the spirit of Verlichting, Aufklaerung," remain in thrall to "kampung" civilization and culture.

Decades as a citizen of Indonesia, with its territory that resembles a string of volcanoes and its inhabitants who are like a range of another kind of volcano, which at any time can explode without notification, have packed my subconscious with sensory and spiritual experiences.

11 The Dutch and German words for the Enlightenment. 
6 Pramoedya Ananta Toer; Alex G. Bardsley, translator

In detention for fourteen years and two months, stripped of everything altogether, I reflected on all this past experience from underneath the military boot that trampled on me. It all became clearer, that all of this was nothing but a material experience, a sort of historical vicious circle of "kampung" civilization and culture without reorientation inward, or outward either. Meanwhile the birth of whatever it is they call the New Order is nothing other than the repetition of historical events from the second decade of the thirteenth century, mythified by Javanese poets several centuries later as the legend of Gandring.

A youth, described as a scoundrel, ordered a keris from a master-craftsman named Gandring. The customer, Ken Arok, killed Gandring before the keris was finished. Of course all this was done in secret. Secretly too, the blade was lent to Kebo Ijo, who went everywhere showing off his borrowed keris, and acting like it was his own. On one occasion Ken Arok stole it [back], and with it he killed the ruler of Singasari. Kebo Ijo was sentenced to death and Ken Arok replaced Tunggal Ametung as lord. Master Gandring, before breathing his last, was able to utter a curse: "Arok, his children and grandchildren, 7 kings in all, will die by this keris!" 12 History shows that several kings were indeed killed, though not quite seven. Still the pattern of the last two decades of the thirteenth century has recurred and recurred unnoticed, in several variations. And in this twentieth century, still in Java, Master Gandring was incarnated in Soekarno himself, the Founder of the Pancasila.

This son [Arok] of the village of Pangkur (up through the twentieth century there has been but one village of this name, in Pangkur subdistrict, Ngawi regency) is not reported to have received the education standard for his time. What is reported is that he was the son of Brahma, Shiva, and Vishnu all at once. It is clear that he was a clever child, a daredevil, and bright. Perhaps because his level of education was minimal, or rather non-existent, under the protection of the chief gods, with power in hand, he closed the era of Javanese Hinduism and began the era of Hindu Javanism. ${ }^{13}$ The largest burial temple in East Java, Kagenengan, was his burial temple, even though nothing is left of it.

Ken Arok of the thirteenth century came to me while I was in exile on Buru. Without Buru he would probably not have met me, and would have remained caged

12 Cf. N. J. Krom, Zaman Hindu, Arif Effendi, trans. (Djakarta: P. T. Pembangunan, 1954), pp. 164-73, at p. 170.

13 Compare this passage form Pramoedya's Nyanyi Tunggal Seorang Bisu (n.p., n.d.) p. 50.

“Révolusi tak pernah dikenal olèh Mahabharata dan Ramayana. Sesuatu yang baru. Dan petani-petani itu apakah pernah tahu di permukaan bumi ini sudah banyak kali terjadi révolusi? Juga nènèk-moyangnya sendiri pernah, sekalipun para pujangga tidak pernah menyebutkan: Révolusi Arok, pembuka kurun baru, dari Hindu-Jawa ke Jawa-Hindu. Yang sekarang juga pembuka kurun baru: dari kolonial ke nasional. Pengganti dan pengganti-pengganti Arok tidak meneruskan, cuma kembali ke awal baheula, bertékad kembali memasuki lingkaran sètan. ..."

[Revolution was never recognized by the Mahabharata and the Ramayana. Something new. And those farmers, did they realize that, on the face of this earth, revolutions had taken place many times? And that their own ancestors, too, had taken part [in one], even though the poets never mentioned it: the Revolution of Arok, opener of a new era, from Javanese Hinduism to Hindu Javanism. The present [revolution] is also the opener of a new era: from colonial to national. Arok's successor and replacements did not continue it, [but] merely returned to an ancient starting point, intentionally reentering the vicious circle.... ] 
in legend. The chief gods of the thirteenth century are still those of the twentieth: the lords of capital, technology, and information. Only, when I wrote the story Arok and Dedes in exile on Buru, I dressed them up with a new interpretation so they could come out of the cage of legend.

Of course there will be some who disagree with this idea. And indeed I do not look for anyone's agreement. On the contrary, any one at all can have her or his own ideas, especially if the one concerned has never been treated as I have been: in particular, exiled for ten years in a forced labor camp on Buru. A fellow political prisoneralready I have forgotten his name-put the question [to me]: can the cycle of Arok not be replaced with a different image? It can, and each person can create it for himself if he has the concern, interest, and will, as long as he does not forget the pattern of "kampung" civilization and culture, that self-same vicious circle, which can only be broken by a reevaluation of it, Verlichting, Aufklaerung, that produces the creativity to break through its own ceiling.

Of course the New Order will pass judgment on this with its cliché: that is, I am defending the PKI. The New Order has the right to defend itself. What is clear, though, is that at the time, the party was valid, legal, one of the winning contestants in the elections, and because of this it also had several ministers in the cabinet. It would never stage a coup against its own success. A coup is typically staged by the party that loses the elections, or does not even participate in them.

Dr. J. Krom once stated that the adventures of Arok before coming to power resemble a "schelmen roman." 14 True. It is also true that in the conception of power à la Java, ${ }^{15}$ and perhaps also for other peoples and ethnicities in the world with "kampung" civilization and culture, it is only supernatural power that makes it possible for something to happen. Thus the reign of a particular person on the throne of power can only come about with its blessing. This is one more indication of the ideals of Javanese culture about power. Power is God's blessing, and he who achieves it becomes the second person after God. With power every crime is cleansed, even legitimized, made good. Then there follow writings and statements from those who share in profiting from it.

Once when I was small I was told the tale, and also learned from books, that evil would be defeated by good. What I was never told is that, naturally, good would also be defeated by evil. A link in a continuous chain. If there were no such chains, one would no longer know good men from bad. A never-ending vicious circle.

As a writer of course I am asked questions that are incomparably clichéd: will you write about the present? Haven't you already written a lot about past times that are already history? What is more, the present is also history, contemporary history, right? ${ }^{16}$

\footnotetext{
14 "Pulp fiction," perhaps.

15 See Anderson, "The Idea of Power in Javanese Culture," in his Language and Power, pp. 17-77.

${ }^{16}$ In Nyanyi Tunggal, Pramoedya records Mochtar Lubis as asking, on a visit to Buru, "Kau sudah mulai menggarap sejarah? Mengapa bukan yang sekarang?" [You've started to tackle history. Why not the history of the present?] To which Pram replies, "Aku sudah muak tentang hal-hal yang tidak menyenangkan sekarang ini. ... " [I'm sick of all the unpleasant things nowadays ... ], p. .34.
} 
Indeed many scholars (and many more to come) publish their research on various aspects of the New Order. They help us in many ways to understand many things. But as a person and a writer who shares in bearing [ikut memikul] the burden of change, I look at it according to national criteria. The era of Soekarno and the Trisakti doctrine was nothing but a sort of thesis. The New Order, an antithesis. Therefore, for me, it is something that in fact cannot be written about yet, a process that cannot yet be written as literature, that does not yet constitute a national process in its totality, because it is in fact still heading for its synthesis.

While I was still at Buru, an Indonesian journalist who behaved like a prosecutor, put me the question, did I not bear a grudge toward the New Order? This is a national process, not a matter for personal grudges. The stories we tell are just a reflection of the level of our own civilization and culture. The progress and variety of technology, statistics about development or even foreign debt, the improvement of communications infrastructure over the colonial legacy, the destruction of the forests and the yearly pack of floods: all occupy their place among the ornamentation of the antithesis in the national process. In the colonial period, the Dutch exported armed paid killers, in uniform, and with military ranks, to subjugate and control areas beyond Java and Madura. Starting in 1904, and sporadically before that, the Dutch sent Javanese beyond Java-Madura without guns-but with hoes. Apparently they knew the demographic and geographic map of Indonesia well enough to come to the classic, profitable conclusion. And apparently the Dutch also knew that their replacements would not be able to do anything but continue [the policy]. No longer occupying a place among the ornamentation of the thesis or even the antithesis, it appears as the nature Indonesia was born with.

One more irony: Indonesia, which was unified politically and administratively by Soekarno without spilling blood-an exceptional occurrence in humanity's historyhas to have its unity and integrity guarded in the colonial tradition, that is, with two Javanese exports: armed mercenaries and Javanese with hoes. With a tradition like that, Indonesia has a serious genetic flaw. Semaoen-a private advisor to President Soekarno-once offered therapy for this genetic defect: move the capital out of Java, to Palangkaraya, in central Kalimantan. But the late Semaoen did not have the chance to experience what is happening to our forests in Kalimantan nowadays. To digest this problem in fiction will surely take a long time, and still may not satisfy the writer or the reader. And the condition of "kampung" civilization and culture would make the writer a target of the power that feels its stability threatened. Of course, by writers I mean those who attempt to make an appraisal and reappraisal of the "kampung" civilization and culture that have consolidated an élite stratum within society. Also the intellectuals, and the small groups in society that are already enlightened, but principally the writers, because their profession is not tied to an academic discipline. Their concern is for the expression of their private conscience and subconscious, while those in power-meaning big shots, not leaders-are busy building a cordon sanitaire around their establishment. As individuals, who are armed only with their own selves, writers are naturally under the greatest pressure. Still, whatever befalls them, their personal experience is also the experience of their people, and the experience of their people is also their personal experience. A part of this experience, small or large or the whole lot, will erupt in their writings, and will return to their people in the form of 
new realities, literary realities. That is why the truth of fiction is also the truth of history.

When as a writer I have to bear so much injustice in my own homeland; physical and mental torment; the theft of freedom and livelihood, rights and property; humiliation and accusation; even the theft of the right to defend myself in the mass media or even in court; I can only nod in understanding. It is a pity that power cannot steal self-respect, personal pride, and everything that lives in people's hearts.

The anxiety that stability-known since the colonial era as rust en orde, and [later] Free-Indonesianized as "security and orderliness"17 - might be disturbed frequently gives rise to ridiculous accusations.

Both before and while [we were] on Buru the charge continually spouted by the New Order, without ever showing evidence, was [that wel wanted to change the Pancasila and the ' 45 Constitution. Usually it was proclaimed in front of a rally or during indoctrination. One of the principles of the Pancasila is Just and Civilized Humanism. By the criterion of humanism, even without the addition of "just and civilized," their treatment of us was quite disgusting, even sickening. The charge of changing the Constitution? Once I heard an officer boast: East Timor? Huh, in two days we can take it. And true, East Timor was latter annexed, the eastern part of the island of Timor that had never been claimed by the founders of the Republic who composed the Constitution of ' 45 . Those two charges led me to the certain conclusion, that what they charged was precisely what they were doing or wanted to do. Because a number of events fit my conclusion, I was sometimes inclined to consider it a formula. But later I softened it to: what is stated as $x$ is minus $x$.

In private conversation several officials deplored my membership in LÉKRA. So according to the New Order's image, LÉKRA was a criminal organization. To this day I have never regretted being made a member of LÉKRA's Pleno, [or being] later promoted to deputy head of the Institute for Literature, [or becoming] one of the founders of the Multituli Academy, all sponsored by LÉKRA. In fact I am proud to have received such great honors, which are not given to just anybody, and it would not lessen my pride if in fact they were front organizations for the PKI. All that has passed, but not yet become history, because as a process it has yet to reach a resolution in synthesis. While I was still on Buru, it turned out that the top person in LÉKRA and the top person in the Institute for Literature had long been freed. Maybe if I were not a writer, I would not have experienced all this sickening treatment. But on the other hand, everything I experience forms part of the foundation of my "author-ization" for the days to come if, perhaps, my age allows it and my physical and mental health can still be relied upon.

$X$ minus $x$ really helps me understand the New Order, which they think will be eternal in its newness. As the last round of political prisoners to leave Buru island, we still had to perform corvée labor by making two kinds of letters of declaration, in umpteen copies. One stated we would not spread Marxism, Leninism, Communism, bogeys that they made up themselves to terrify themselves with. The other was a declaration that as political prisoners we had been treated properly on Buru island.

\footnotetext{
17 Pramoedya takes the nationalist slogan Indonesia Merdèka, makes it a verb, and with it transforms the
} watchwords of the Dutch colonial state into a fussier euphemism for control. 
Legally, these corvee letters were a joke, but with them we could buy numbers for embarkation on ships leaving for Java. How lovely if perhaps these corvée letters are stored carefully in the state archives. The papers will then become part of the history of how so many Indonesians made masks-and-robes of Angels of Sanctity for the powerful and their power. A leader does not need a mask and robe. ${ }^{18}$

By the pier at Namlea, where the ship Tanjungpandan was ready to board, five hundred of the last group who were to depart for Java had already left the shore. A dozen or so were left, including myself. Lt. Col. Lewirisa, commandant of the last camp, came to me and said unasked and unexpectedly, "Pram, the voyage is straight to Jakarta." That meant $x$ minus $x$, that our party of a few dozen would not be going to Jakarta. Only then were we permitted to board the ship, where we were separated from the others.

The forced labor camp we had left had at first been named Tefaat, the place of exploitation of our labor, for the rest of our lives: [where we] had to pay to live, for housing, the road network, economy and environment; [where we had] to make paddyfields and dry fields out of grassland and jungle; and [where in addition we] had to provide food to the soldiers who guarded us, despite the murders of a number of us. According to the written corvée, this must be called proper. Also those who died in forced labor to bring in money. Also the payment of taxes-for whom and to whom is not clear-by political prisoners who did crafts and handiwork. According to the written corvée, this too must be called proper. And buildings, tens of them, large and small, with household furnishings, all built and paid for by political prisoners: it must be deemed proper when these are sold to another agency without any compensation to the political prisoners. Also the casual theft of their cattle. And all this really is on its way towards history, but it is not history yet. The list [of abuses] goes on and on. All the banditry, large and small, will be brought home to this people, my people, who brought into being a power of this kind. It is not my intention to erect a utopian world with this people, to inhabit an unblemished corner of the world-other peoples too have their dark side-what I mean is that this people has not yet brought to life the slightest enlightenment, Verlichting, Aufklaerung. The Brahmins still occupy their position as the [fashion] accessories to the power of the warrior caste, who live from and for power alone, because they really are not productive let alone creative, just as in the precolonial era. It is not surprising if in thousands of texts, the contents revolve around the "terrific"-ness of the warriors in killing those they think oppose them, and the contents of thousands more texts are prescriptions for the happy life (in a world of stifled existence), and advice on behaving gracefully and well (in a world of banditism), and about the spirit world and techniques of communicating with it (in an atmosphere of no longer recognizing one's own surroundings).

What Lt. Col. Lewirisa said was precisely minus $x$. Before the ship arrived at Jakarta, the dozen or so of us were taken off at Tanjungpèrak, Surabaya, to be put away on the prison island of Nusa Kambangan, off south Java. Only through the good offices of the international press, which made a fuss about it, did we finally reach Jakarta, to enter a new jail that allowed more latitude. [I have been] under city arrest

18 Some members of the mob that attacked Pramoedya's house on the night of October 13, 1965, wore masks. 
since the end of 1979 through the end of 1991, without any court ruling whatsoever. Many new accusations have been leveled, which as a writer of course enriches the material I have to let settle. At the very least, it makes the story of a writer's life that much longer.

With the relative freedom of being under city arrest, I have been able to follow the news inside the country and abroad. The chain of accusations turned out to come from Indonesia itself and as far as parts of East Asia and Europe: that in Soekarno's time I prohibited the publishing of a number of works by my fellow writers; that I terrorized Indonesian writers who were not of the same mind by my article, "What Must Be Felled and What Must Be Built." 19 A well-known literary figure, giving a lecture at a state university, even declared that he had been fired because of my actions. It happens that this figure, like a number of other [accusers], was an official with the occupying Dutch armed forces during the revolution, while some of the other [accusers], because of their age, did not of course participate in the revolution at all.

The dismissing of people from office is not my business, and never has been. Such accusations are only a smoke screen for what they themselves have done and want to do. In the early days of the events of 1965 it was they who terrorized, and they who destroyed all my papers, including the manuscripts of Just Call Me Kartini, volumes 3 and 4; A Collection of Kartini's Works; Women Before Kartini; A Collection of Bung Karno's Short Stories; the last two volumes of the trilogy The Girl From the Coast; A Study of Abdullah bin Abdul Kadir Munsyi; and A Preliminary Study of the History of the Indonesian Language. When the director of the Balai Pustaka responded to my request to get back the two volumes of Pre-Indonesian Literature, the answer was: they had already been burned at the request of his superiors.

One important literary figure who under the Old Order appointed me his adversary once told me the names of important literary figures of the time who joined in the attack on my house in 1965. In fact, before the attack they got a request, from a literary figure of the older generation, to take the manuscript of the Encyclopedia of Indonesian Literature I was in the process of compiling.

At the beginning of the ' $80 \mathrm{~s}$, Beb Vuyk in the Netherlands launched the accusation, that LÉKRA had sent "knokploeg" 20 to beat up its enemies. Among the [alleged] victims was the musicologist Bernard Ijzerdraat. In the Netherlands the issue of knokploeg seems to survive as the end of 1991 approaches. When Beb Vuyk came to Indonesia for the last time and met this same musicologist, she got a disavowal from him. Nevertheless she never retracted her accusation. They, on the other hand, have killed several members of LEKKRA, among them being the national sculptor Trubus, while he was en route to Jakarta in answer to President Soekarno's summons. Until this day no one has admitted responsibility for it, nor for the murder of hundreds of thousands of their own brothers and sisters. Very different from what in the North are called terrorists, who as soon as they take action, declare themselves responsible for it: they have no need for angel-masks and angel-robes. Never mind mass murder, the smallest

${ }^{19}$ Pramoedya Ananta Toer, "Jang Harus Dibabat dan Harus Dibangun," Bintang Timur, August 10, September 1 and 7, and October 12,1962. The expressions babat and bangun refer to things, like jungle and houses, or figuratively to structures or systems, not to people.

${ }^{20}$ Goons, thugs. 
12 Pramoedya Ananta Toer; Alex G. Bardsley, translator

of thefts is criminal, and all of it can happen only because of "kampung" civilization and culture, the social culture and civilization of peoples who are isolated, who feel insecure and threatened because of their own acts, and for whom masks and robes of holiness become the uniform of a parade fascinating enough to be staged as a comicbook drama.

One can imagine how awesome is the task of dealing with all this unfinished business in a work of literature. Not to mirror or reflect events, because the task of literature is not to take pictures, but to change upstream realities to become a literary reality, that will carry its readers further forward than the established order.

Is such an attitude a subversive attitude, or a criminal one? That too is up to Messrs. the powerholders, who have soldiers, police, and administrative staff. Their actions are nothing but what the level of their civilization and culture will permit. If it should happen that they progress beyond the measure of their civilization and culture, and one hopes it will be so, this could be a positive sign that Gandring's curse on seven generations of descendants will not be "in effect" for even two generations, because the stage of synthesis is at the door. It is clear, however, that, like it or not, everything that has happened will live on for centuries in the memory of this people and of humanity. Writers will bring it to life more clearly in their works, within which the killers and the killed will be immortal, instead of just actors in history. The holy robes and masks will be scattered. ${ }^{21}$

Once more-my apologies.

Jakarta, November 1991

${ }^{21}$ The reference, pointed out to me by Ben Anderson, is to Chairil Anwar's poem, "Krawang-Bekasi," 1948:

“.../Kami cuma tulang-tulang bersèrakan

Tapi adalah kepunyaanmu

Kaulah lagi yang tentukan nilai tulang-tulang bersèrakan.

Ataukah jiwa kami melayang untuk kemerdèkaan, kemenangan dan harapan

atau tidak untuk apa-apa,

kami tidak tahu, kami tidak lagi bisa berkata

Kaulah sekarang yang berkata...."

IWe are only scattered bones

But in your possession

It is you too who set the value of scattered bones.

Whether our souls did depart for freedom, victory and hope

or for nothing,

we do not know, we no longer can speak

It is you now who speak.] 


\title{
AFTERWORD
}

\author{
Alex G. Bardsley
}

"The New Order needs the tapol issue-it is a problem they can be grateful for. They will keep it as an issue, maturing, occasionally airing it in public, but never solve it definitively by granting a blanket amnesty. I know it doesn't make sense to continue to make a bogey out of these broken men, but not making sense is the character of a repressive regime." - Yusuf Ishak ${ }^{22}$

Pramoedya's essay is an unusual document, and some comment on its background is probably in order. Some five years after it was written, things are still much as he described them: his movements are restricted, his writings banned, and after a spate of interviews published when he won the Magsaysay award last summer, he is again a non-person to the Indonesian media. To whom and for whom, then, did he write the essay?

Thirty years have passed since the massacres of 1965-66, yet an anxiety persists about whether the violence can, will, or perhaps must inevitably happen again. The business of managing this anxiety informs much of New Order political culture, the principal technique being to locate agency elsewhere, outside Indonesian society. For the killings themselves, the victims have been blamed. They have, moreover, been made to represent an ideological force, communism, "foreign" to Indonesian culture. The present rulers, by contrast, represent their regime as "indigenous" and culturally pure, as legitimate as if they were parthenogenetically descended from the "successful kings" of yore. The New Order secures past history by an indigenist exclusion of the causes of change-but communism has left a lot of Indonesian ghosts.

Dead, imprisoned, exiled, or ostracized, they are in no position to start anything. Yet on them is projected the guilt of the winners and survivors, carrying a charge so powerful that the victims frequently seem-in language that, borrowed straight from horror movies, irrupts unnervingly today into newspaper headlines and on magazine covers-about to rise from the grave. ${ }^{23}$ And rather as a sick person's family will pay anything, not for a cure, but just for hope, so many Indonesians hardly count the cost of keeping their fear in remission. ${ }^{24}$ The New Order's second legitimating function is to secure the present against the ghosts of the past.

As a particularly prominent ghost, Pramoedya has been a target of recurrent demands that he apologize for, or at least admit, his role in causing (through literary

22 Inside Indonesia 20 (October 1989): 31. Tapol, or tahanan politik: political prisoner.

23 This phenomenon was brought to my attention by Ben Abel, Echols Collection, Cornell University.

24 On institutionalized fear, see Amrih Widodo, "The 'Roh' of the System: on the Unification of Meaning and Expression in a Contemporary Indonesian Novel," Indonesia 40 (October 1985): 75-88. 
14 Pramoedya Ananta Toer; Alex G. Bardsley, translator

criticism!) a "national disaster." 25 His answer in this essay is to confess-to being Javanese. He ascribes, for the sake of argument, a whole history of fratricidal conflict to the enabling role played by Javanese culture, ${ }^{26}$ setting New Order indigenism against its security (ghost-busting) function. If culture is destiny, then the blood-bath is repeatable. And the damning characteristics of that culture are the mystification and personalization of politics.

It is here that the essay's intended readership almost comes into view. Mystification of the relations of power is still the job of court poets and brahmins, and among these are Pramoedya's accusers. The piece is strewn with "you-know-who-youare" references that, with one exception, I have not elaborated on in the footnotes. Pramoedya has reason for his reticence. His principal "crime" seems to have been "terrorizing" his colleagues by mentioning them in literary polemics by name: something that was taken very personally by those who do not distinguish between person and role. Pramoedya's "apology" is addressed to them, on behalf of his fellow ghosts and their scattered bones.

\footnotetext{
${ }^{25}$ Lukman Ali's comments are fairly typical:

“Melalui ruang 'Lentera' koran Bintang Timur, Pramoedya dengan amat leluasa menikamkan keris révolusionèrnya ke kiri dan ke kanan dalam rangka memenangkan apa yang disebutnya 'sastra révolusionèr.' Untuk sebagian, maksud ini tercapai sampai pecah pemberontakan G.30s./PKI. Akhirnya, ia ikut terkubur (untuk sementara?) bersama situasi, dengan keyakinan untuk timbul kembali bila keadaan sudah meyakinkan ....

"Hanya kita tak pernah mendengar adanya pernyataan bersalah dan permintaan maaf darinya tentang ucapan dan perbuatannya selama ini. Lalu, siapa yang salah selama ini? Apakah dirinya tidak ikut bertanggungjawab terhadap malapetaka nasional yang ditimbulkan PKI?" Lukman Ali, "Sastra Bukan Untuk Révolusi?,"Republika, August 19, 1995.

[Through "Lentera's" space in the paper Bintang Timur, Pramoedya thrust his revolutionary keris unchecked to left and right, in his designs for what he called 'revolutionary literature' to prevail. For some, this purpose was reached to the point where the G.30S./PKI rebellion broke out. In the end, he too was buried (temporarily?) along with the situation, assured of emerging again once conditions were more encouraging....
}

Only we have never heard of there being any statement of fault or apology from him for his statements and actions in all this time. So, who has been wrong all this time? Does he not also share responsibility for the national disaster brought about by the PKI?]

${ }^{26}$ Pramoedya wrote of Indonesia's history of fratricidal conflict long before 1965:

"Tapi dari dulu hingga kini: Indonesia terus-menerus mengalami perang saudara-lahir batin. Dan perang itu terdjadi di semua daerah pendjadjahan. Pangreh Praja melawan kepentingan rakjat. Polisi melawan gerakan kemerdèkaan bangsanja sendiri. Murid-murid sekolah pemerintah melawan muridmurid sekolah pribumi di dusun, gunung dan kampung dan djuga sekolah pribumi di kota.

Sesungguhnja, orang Indonesia diperangi olèh orang Indonesia sendiri-dari Sabang sampai Merauke. Dan pula perang saudara ini berlaku dari abad ke abad ... "Pramoedya, "Gado-gado," Pertjikan Révolusi (Djakarta: Gapura, 1950), p. 31.

[But from the past through the present day: Indonesia has continually experienced civil war-in thought and deed. And such wars also occur in all zones of colonial domination. The civil service opposes the interests of the people. The police oppose their own nation's independence movement. Students from government schools oppose native school students in remote hamlets, mountains, villages and even in the city. In actuality, Indonesians are warred upon by the Indonesians themselves-from Sabang to Merauke. And this civil war persists from century to century as well .... ] 